\title{
Infeksi Respiratorik Bawah Akut pada Anak
}

\author{
Bambang Supriyatno
}

Infeksi respiratorik akut dibagi menjadi 2 kelompok besar yaitu infeksi respiratorik atas akut (IRAA) dan infeksi respiratorik bawah akut (IRBA), yang menjadi masalah utama adalah pneumonia dan bronkiolitis. Pneumonia merupakan ancaman baik kesakitan maupun kematian pada bayi khususnya bayi muda. Pengobatan utama adalah pemberian antibiotik yang sesuai dengan penyebabnya. Masalahnya adalah penyebab pneumonia sulit diketahui secara pasti karena tidak dilakukan kultur darah, sehingga pemberian antibiotik hanya berdasarkan empiris. Mengenai manfaat pemberian obat suportif lain seperti vitamin A, Zn masih memerlukan penelitian lebih jauh. Sementara itu bronkiolitis yang disebabkan oleh virus terutama RSV (respiratory syncitial virus) masih merupakan kendala bagi kesehatan anak di Indonesia; sehingga pengobatan bronkiolitis masih merupakan perdebatan yang panjang. Penggunaan antibiotik tidak diperlukan, pemberian anti virus ribavirin, kortikosteroid sistemik, dan pemberian bronkodilator masih memerlukan analisis yang mendalam. Pernah dilaporkan pemberian RSVIG pada kasus yang berat, hasilnya masih belum memuaskan karena tidak berbeda bermakna dengan pemberian albumin disamping pengobatan suportif lainnya.

Kata kunci: pneumonia, bronkhiolitis, infeksi respiratorik bawah akut

7 nfeksi respiratorik akut (IRA) merupakan penyebab terpenting morbiditas dan mortalitas pada anak. Infeksi respiratorik adalah infeksi yang terjadi mulai dari respiratorik atas dan adneksanya hingga parenkim paru. Sedangkan yang dimaksud infeksi respiratorik atas adalah infeksi primer respiratorik di atas laring, sedangkan infeksi laring ke bawah disebut infeksi respiratorik bawah. ${ }^{1}$

Infeksi respiratorik atas akut (IRAA) terdiri dari rinitis, faringitis, tonsilitis, sinusitis, dan otitis media.

\footnotetext{
Alamat korespondensi:

Dr. Bambang Supriyatno Sp.A(K) Divisi Respirologi Departemen Ilmu Kesehatan Anak FKUI-RSCM Jl. Salemba no. 6, Jakarta 10430. Telepon: 021-3100669. Fax.021-390 7743.
}

Sedangkan infeksi respiratorik bawah akut (IRBA) terbagi atas croup (epiglotitis dan laringo-trakeobronkitis), bronkitis, bronkiolitis, dan pneumonia. Sebagian besar IRA biasanya terbatas pada IRAA saja, tapi sekitar lima persen diantaranya melibatkan laring dan respiratorik bawah berikutnya, sehingga berpotensi menjadi serius. Kasus IRBA (sebagian besar pneumonia) menyebabkan kematian sekitar 4 juta anak pertahun, kira-kira 1/3 dari seluruh kematian anak di negara berkembang. ${ }^{2}$

Penyebab utama pneumonia adalah infeksi bakteri sehingga penggunaan antibiotik mempunyai dasar yang kuat, sedangkan bronkiolitis penyebab utamanya adalah virus terutama RSV (respiratory syncitial virus). ${ }^{2}$ Pembahasan dalam makalah ini dibatasi pada kasus IRBA terutama pneumonia dan bronkiolitis. 


\section{Pneumonia}

\section{Definisi}

Pneumonia adalah inflamasi yang mengenai parenkim paru; walaupun banyak pihak yang sependapat bahwa pneumonia adalah suatu keadaan inflamasi, namun sangat sulit untuk merumuskan satu definisi tunggal yang universal. Pneumonia adalah sindrom klinis, sehingga didefinisikan berdasarkan gejala dan tanda klinis, dan perjalanan penyakitnya. Salah satu definisi klinis klasik menyatakan pneumonia adalah penyakit respiratorik yang ditandai dengan batuk, sesak napas, demam, ronki basah, dengan gambaran infiltrat pada foto rontgen toraks. ${ }^{1}$ Dikenal istilah lain yang mirip yaitu pneumonitis yang maksudnya lebih kurang sama. Banyak yang menganut pengertian bahwa pneumonia adalah inflamasi paru karena proses infeksi sedangkan pneumonitis adalah inflamasi paru non-infeksi. Namun hal inipun tidak sepenuhnya ditaati oleh para ahli. ${ }^{1}$

\section{Etiologi}

Sebagian besar pneumonia disebabkan oleh mikroorganisme (virus/bakteri) dan sebagian kecil disebabkan oleh hal lain (aspirasi, radiasi, dan lain-lain). ${ }^{2}$ Pada pneumonia pertanyaan penting adalah apa penyebabnya, virus atau bakteri? Penyebab tersering adalah bakteri, namun seringkali diawali oleh infeksi virus yang kemudian mengalami komplikasi infeksi bakteri.

Pola kuman penyebab pneumonia biasanya berbeda sesuai dengan distribusi umur pasien. ${ }^{3}$ Secara umum bakteri yang paling berperan penting dalam pneumonia adalah Streptococcus pneumoniae, haemophilus influenzae, Staphylococcus aureus, streptokokus grup B, serta kuman atipik klamidia dan mikoplasma. (Tabel 1)

\section{Faktor risiko}

Beberapa keadaan seperti gangguan nutrisi (malnutrisi), usia muda, kelengkapan imunisasi, kepadatan hunian, defisiensi vitamin $A$, defisiensi Zinc (Zn), dan faktor lingkungan (polusi udara) merupakan faktor risiko untuk IRBA. ${ }^{4}$ Pada keadaan malnutrisi selain terjadinya penurunan imunitas seluler, defisiensi $\mathrm{Zn}$ merupakan hal utama sebagai faktor risiko pneumonia. ${ }^{5}$ Penelitian meta-analisis menunjukkan bahwa pemberian vitamin A pada anak dapat menurunkan risiko kematian karena pneumonia. Kejadian IRBA meningkat pada anak dengan riwayat merokok atau perokok pasif. ${ }^{6}$

\section{Patogenesis}

Sebagian besar pneumonia timbul melalui mekanisme aspirasi kuman atau penyebaran langsung kuman dari saluran respiratorik atas. Hanya sebagian kecil merupakan akibat sekunder dari viremia / bakteremia atau penyebaran dari infeksi intraabdomen., ${ }^{3,7}$ Dalam keadaan normal saluran respiratorik bawah mulai dari sublaring hingga unit terminal dalam keadaan steril. Paru terlindung dari infeksi dengan beberapa mekanisme: ${ }^{3,7}$

- filtrasi partikel di hidung

- pencegahan aspirasi dengan refleks epiglotis

- ekspulsi benda asing melalui refleks batuk

- pembersihan ke arah kranial oleh selimut mukosilier

- fagositosis kuman oleh makrofag alveolar

- netralisasi kuman oleh substansi imun lokal

- drainase melalui sistem limfatik

Pneumonia terjadi jika satu atau lebih mekanisme di atas mengalami gangguan.

Tabel 1. Dugaan bakteri penyebab pneumonia ${ }^{1}$

\begin{tabular}{lccc}
\hline Dugaan kuman penyebab & $\begin{array}{c}\text { Pneumonia } \\
\text { tanpa komplikasi }\end{array}$ & \multicolumn{2}{c}{ Pneumonia dengan komplikasi } \\
\cline { 2 - 4 } & +++ & Efusi pleura & Abses paru \\
\hline Streptococcus pneumoniae & ++ & ++ & + \\
Haemophilus influenzae & + & ++ & + \\
Streptococcus group $A$ & + & ++ & - \\
Flora mulut & + & ++ & +++ \\
Staphylococcus aureus & & & ++ \\
\hline
\end{tabular}




\section{Manifestasi klinis}

Gejala dan tanda klinis pneumonia bervariasi tergantung dari kuman penyebab, usia pasien, status imunologis pasien, dan beratnya penyakit. Manifestasi klinis biasanya berat yaitu sesak, sianosis, tetapi dapat juga gejalanya tidak terlihat jelas seperti pada neonatus. Gejala dan tanda pneumonia dapat dibedakan menjadi gejala umum infeksi (nonspesifik), gejala pulmonal, pleural, atau ekstrapulmonal. Gejala nonspesifik meliputi demam, menggigil, sefalgia, resah dan gelisah. Beberapa pasien mungkin mengalami gangguan gastrointestinal seperti muntah, kembung, diare, atau sakit perut. ${ }^{3}$ Gejala pada paru timbul setelah beberapa saat proses infeksi berlangsung. Setelah gejala awal seperti demam dan batuk pilek, gejala napas cuping hidung, takipnu, dispnu, dan timbul apnu. Otot bantu napas interkostal dan abdominal mungkin digunakan. Batuk umumnya dijumpai pada anak besar, tapi pada neonatus bisa tanpa batuk. ${ }^{3}$

Frekuensi napas merupakan indeks paling sensitif untuk mengetahui beratnya penyakit. Hal ini digunakan untuk mendukung diagnosis dan memantau tata laksana pneumonia. Pengukuran frekuensi napas dilakukan dalam keadaan anak tenang atau tidur. Tim WHO telah merekomendasikan untuk menghitung frekuensi napas pada setiap anak dengan batuk. Dengan adanya batuk, frekuensi napas yang lebih dari normal serta adanya tarikan dinding dada bagian bawah ke dalam (chest indrawing), WHO menetapkan sebagai pneumonia (di lapangan), dan harus memerlukan perawatan dengan pemberian antibiotik. Perkusi toraks pada anak tidak mempunyai nilai diagnostik karena umumnya kelainan patologinya menyebar; suara redup pada perkusi biasanya karena adanya efusi pleura. ${ }^{3}$ Suara napas yang melemah seringkali ditemukan pada auskultasi. Ronkhi basah halus yang khas untuk pasien yang lebih besar, mungkin tidak terdengar pada bayi. Pada bayi dan balita kecil karena kecilnya volume toraks biasanya suara napas saling berbaur, dan sulit untuk diidentifikasi. ${ }^{3}$

Secara klinis pada anak sulit membedakan pneumonia bakterial dengan pneumonia viral. Namun sebagai pedoman dapat disebutkan bahwa pneumonia bakterial awitannya cepat, batuk produktif, pasien tampak toksik, leukositosis, dan perubahan nyata pada pemeriksaan radiologis. ${ }^{8}$ Namun keadaan seperti ini kadang-kadang sulit dijumpai pada seluruh kasus.

\section{Pemeriksaan penunjang}

Diagnosis pneumonia terutama didasarkan gejala klinis, sedangkan pemeriksaan foto rontgen toraks perlu dibuat untuk menunjang diagnosis, selain untuk melihat luasnya kelainan patologi secara lebih akurat. Foto torak antero proterior (AP) dan lateral dibutuhkan untuk menentukan lokasi anatomik dalam paru, luasnya kelainan, dan kemungkinan adanya komplikasi seperti pneumotoraks, pneumomediastinum, dan efusi pleura. Infiltrat tersebar paling sering dijumpai, terutama pada pasien bayi. Pembesaran kelenjar hilus sering terjadi pada pneumonia karena $H$. influenzae dan $S$. aureus, tapi jarang pada pneumonia $S$. pneumoniae. Adanya gambaran pneumatokel pada foto toraks mengarahkan dugaan ke $S$. aureus. Kecurigaan ke arah infeksi $S$. aureus apabila pada foto rontgen dijumpai adanya gambaran pneumatokel dan usia pasien di bawah 1 tahun. Foto rontgen toraks umumnya akan normal kembali dalam 3-4 minggu. Pemeriksaan radiologis tidak perlu diulang secara rutin kecuali jika ada pneumatokel, abses, efusi pleura, pneumotoraks atau komplikasi lain. ${ }^{3}$ Sebagaimana manifestasi klinis, demikian pula pemeriksaan radiologis tidak menunjukkan perbedaan nyata antara infeksi virus dengan bakteri. Apabila dijumpai adanya gambaran butterfly di sekitar jantung /parakardial maka kemungkinan infeksi oleh virus.

Pada sebagian besar kasus, pemeriksaan ekstensif tidak perlu dilakukan, tapi pemeriksaan laboratorium mungkin membantu dalam memperkirakan kuman penyebab. Leukositosis hingga $>15.000 /$ ul seringkali dijumpai. ${ }^{3}$ Dominasi neutrofil pada hitung jenis atau adanya pergeseran ke kiri menununjukkan bakteri sebagai penyebab. Leukosit >30.000/ul dengan dominasi neutrofil mengarah ke pneumonia streptokokus.,7

Laju endap darah dan $C$-reactive protein (CRP) indikator inflamasi yang tidak khas sehingga hanya sedikit membantu. Adanya CRP yang positif dapat mengarah kepada infeksi bakteri. Biakan darah merupakan cara yang spesifik untuk diagnosis namun hanya positif pada 10\%-15\% kasus terutama pada anak kecil. Adanya efusi pleura menguatkan dugaan bakteri sebagai penyebabnya. Empiema lebih banyak dijumpai pada anak $<2$ tahun dan pada laki-laki. ${ }^{9}$

\section{Diagnosis}

Diagnosis pneumonia yang terbaik adalah berdasarkan etiologi, yaitu dengan pemeriksaan mikrobiologik. 
Sari Pediatri, Vol. 8, No. 2, September 2006

Tabel 2. Pedoman klinis membedakan penyebab pneumonia

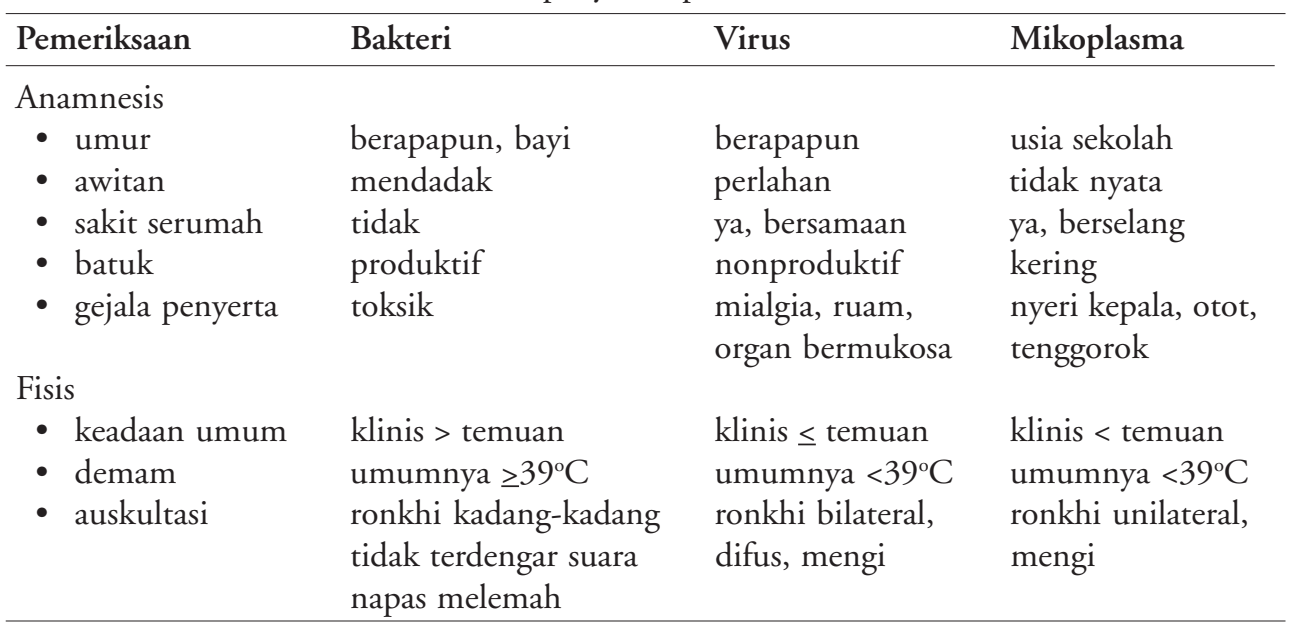

Sayangnya pemeriksaan ini banyak sekali kendalanya, baik dari segi teknis maupun biaya. Bahkan dalam penelitianpun kuman penyebab spesifik hanya dapat diidentifikasi pada kurang dari 50\% kasus. ${ }^{9}$ Dengan demikian diagnosis pneumonia terutama berdasarkan manifestasi klinis, dibantu pemeriksaan penunjang lain.

Tanpa pemeriksaan mikrobiologik, kesulitan yang lebih besar adalah membedakan kuman penyebab; bakteri, virus, atau kuman lain. Pneumonia bakterial lebih sering mengenai bayi dan balita dibanding anak yang lebih besar. Pneumonia bakterial biasanya timbul mendadak, pasien tampak toksik, demam tinggi disertai menggigil, dan sesak memburuk dengan cepat. Pneumonia viral biasanya timbul perlahan, pasien tidak tampak sakit berat, demam tidak tinggi, gejala batuk dan sesak bertambah secara bertahap. Infeksi virus biasanya melibatkan banyak organ bermukosa (mata, mulut, tenggorok, usus). Semakin banyak organ tersebut terlibat makin besar kemungkinan virus sebagai penyebabnya. Pneumonia bakterial bersifat khas yaitu hanya organ paru yang terkena. ${ }^{8}$ Tabel 2 dapat membantu dalam membedakan kuman penyebab pneumonia:

\section{Tata laksana}

Pasien pneumonia mempunyai indikasi untuk perawatan di rumah sakit. Sesak yang terjadi harus ditangani dengan segera. Pneumonia pada bayi di bawah 2 bulan biasanya menunjukkan gejala yang cukup berat. Tata laksana pasien meliputi terapi suportif dan terapi etiologik. Terapi suportif berupa pemberian makanan atau cairan sesuai kebutuhan serta koreksi asam-basa dan elektrolit sesuai kebutuhan. Terapi oksigen diberikan secara rutin. Jika penyakitnya berat dan sarana tersedia, alat bantu napas mungkin diperlukan terutama dalam 24-48 jam pertama. Bagian yang sangat penting dari tata laksana pneumonia adalah pemberian antibiotik.

Idealnya tata laksana pneumonia sesuai dengan kuman penyebabnya. Namun karena berbagai kendala diagnostik etiologi, untuk semua pasien pneumonia diberikan antibiotik secara empiris. Pneumonia viral seharusnya tidak diberikan antibiotik, namun pasien dapat diberi antibiotik apabila terdapat kesulitan membedakan infeksi virus dengan bakteri; di samping kemungkinan infeksi bakteri sekunder tidak dapat disingkirkan.

Streptokokus dan pneumokokus sebagai kuman Gram positif dapat dicakup oleh ampisilin, sedangkan hemofilus suatu kuman gram negatif dapat dicakup oleh kloramfenikol. Dengan demikian keduanya dapat dipakai sebagai antibiotik lini pertama untuk pneumonia anak tanpa komplikasi. Secara umum pengobatan antibiotik untuk pneumonia diberikan dalam 5-10 hari, namun dapat sampai 14 hari. Pedoman lain pemberian antibiotik sampai 2-3 hari bebas demam.

Pada pasien pneumonia community acquired, umumnya ampisilin dan kloramfenikol masih sensitif. Pilihan berikutnya adalah obat golongan sefalosporin atau makrolid. Tabel 3 memperlihatkan anjuran pilihan antibiotik.

Mengenai penggunaan makrolid pada pneumonia telah banyak dilaporkan. Penggunaan azitromisin dan 
klaritromisin pada IRBA sama efektifnya dengan pemberian co-amoksiklav. Pemberian azitromisin tolerabilitasnya cukup baik serta efek sampingnya minimal bila dibandingkan dengan co-amoksiklav. ${ }^{10-}$ ${ }^{11}$ Pemberian azitromisin sekali sehari selama 3 hari efektifitasnya setara dengan pemberian co-amoksiklav selama 10 hari. Penggunaan klaritromisin secara multisenter pada pneumonia mendapatkan hasil yang cukup baik dalam hal efektifitas dan efek sampingnya. ${ }^{12}$ Efek samping gangguan gastrointestinal seperti mual, nyeri abdomen didapatkan pada sebagian kecil pasien yang tidak berbeda bermakna dengan antibiotik lain.

\section{Bronkiolitis}

Bronkiolitis adalah suatu infeksi sistem respiratorik bawah akut yang ditandai dengan pilek, batuk, distres pernapasan dan ekspiratorik effort (usaha napas pada saat ekspirasi). Di Amerika Serikat sekitar 120.000 bayi dirawat dengan bronkiolitis pertahun. Umumnya bronkiolitis menyerang pada anak di bawah umur 2 tahun dengan kejadian tersering kira-kira usia 6 bulan. ${ }^{13}$

\section{Etiologi}

Penyebab tersering adalah RSV (lebih dari 50\%) diikuti oleh virus parainfluenza 3, dan adenovirus. Infeksi oleh adenovirus biasanya dihubungkan dengan komplikasi yang terjadi seperti bronkiolitis obliterans yang sulit ditangani. Kemungkinan kejadian bronkiolitis pada anak dengan ibu perokok lebih tinggi dibandingkan pada anak dengan ibu yang tidak merokok. ${ }^{13}$

\section{Manifestasi klinis}

Umumnya anak pernah terpajan dengan anggota keluarga yang menderita infeksi virus beberapa minggu sebelumnya. Gejala awal yang mungkin timbul adalah tanda-tanda infeksi respiratorik atas akut berupa demam, batuk, pilek, dan bersin. Setelah gejala di atas timbul biasanya diikuti oleh adanya kesulitan bernapas (sesak) yang umumnya pada saat ekspirasi. Pada pemeriksaan fisis didapatkan frekuensi nafas yang meningkat (takipnu), disertai adanya ekspirasi yang memanjang bahkan mengi. ${ }^{14}$ Pada kasus yang berat mengi dapat terdengar tanpa stetoskop. ${ }^{13}$ Pada pemeriksaan penunjang yaitu pemeriksaan radiologis dijumpai gambaran hiperinflasi, dengan infiltrat yang biasanya tidak luas. Bahkan ada kecenderungan ketidaksesuaian antara gambaran klinis dan gambaran radiologis. Berbeda dengan pneumonia bakteri, gambaran klinis yang berat akan menunjukkan gambaran kelainan radiologis yang berat pula, sementara pada bronkiolitis gambaran klinis berat tanpa gambaran radiologis berat. Pada pemeriksaan laboratorium (darah tepi) umumnya tidak memberikan gambaran yang bermakna, dapat disertai dengan limfopenia., ${ }^{9,13}$

Pemeriksaan serologis RSV dapat dilakukan secara cepat, di negara maju pemeriksaan ini menjadi pemeriksaan rutin apabila dicurigai adanya infeksi RSV.

\section{Diagnosis banding}

Bronkiolitis harus dibedakan dengan asma pada anak usia di bawah 2 tahun. Kecurigaan bronkiolitis apabila kejadian sesak merupakan pertama kali sedangkan pada asma selain tanpa disertai demam kejadian seperti ini merupakan kejadian yang berulang. Selain asma, pneumonia karena bakteri pun kadang-kadang sulit dibedakan apabila disertai dengan sumbatan respiratorik karena kaliber saluran yang masih kecil. ${ }^{13}$

\section{Pengobatan}

Sebagaimana telah dibahas di atas penyebab tersering bronkiolitis adalah virus terutama RSV, sehingga sebenarnya tidak pada tempatnya pemberian antibiotik pada bronkiolitis. ${ }^{13}$ Di negara maju untuk membedakan infeksi karena RSV atau bakteri dapat dilakukan dengan cepat yaitu uji serologis terhadap

Tabel 3. Anjuran antibiotik empiris sesuai dengan perjalanan penyakit pneumonia anak

\begin{tabular}{lll}
\hline Pneumonia tanpa komplikasi & \multicolumn{2}{c}{ Pneumonia dengan komplikasi } \\
\cline { 2 - 3 } & Efusi pleura & \multicolumn{1}{c}{ Abses paru } \\
\hline ampisilin + kloramfenikol & sefuroksim & sefazolin \\
sefuroksim & & klindamisin \\
ampisilin + sulbaktam & ampisilin + sulbaktam & ampisilin + sulbaktam \\
\hline
\end{tabular}


RSV dan pemeriksaan CRP. Apabila pemeriksaan serologis terhadap RSV negatif maka tidak diperlukan antibiotik. ${ }^{13}$ Di Indonesia, penggunaan uji serologis terhadap RSV belum rutin dikerjakan sehingga kadang-kadang sulit dibedakan dengan pneumonia bakteri. Van Woensel dkk, ${ }^{14}$ menyatakan masih banyaknya penggunaan antibiotik pada bronkiolitis yang sebenarnya dapat dihindari. Namun karena sulitnya membedakan dengan bakteri terutama superinfeksi oleh bakteri, maka masih digunakan antibiotik, meskipun sebenarnya kurang tepat.

Pemberian anti virus ribavirin secara inhalasi masih merupakan hal yang belum disepakati. Sebagian peneliti mendapatkan hasil yang cukup baik dengan ribavirin tetapi sebagian lain kurang bermanfaat. ${ }^{13-15}$

Pemberian obat-obat lain masih kontroversial. Penggunaan kortikosteroid sistemik masih menjadikan perdebatan yang berkepanjangan. Salah satu penelitian meta-analisis mengambil kesimpulan peran kortikosteroid sistemik pada bronkiolitis adalah bermanfaat dalam hal perbaikan klinis, lama rawat, dan lamanya gejala menghilang. Pada penelitian tersebut dianjurkan pemberian kortikosteroid pada awal penyakit. ${ }^{15}$ Penelitian lain menyatakan bahwa pemberian kortikosteroid pada kasus infeksi respiratorik bawah akut yang memerlukan ventilator kurang bermanfaat. ${ }^{16}$ Selain pemberian obat tersebut, penggunaan bronkodilator juga merupakan perdebatan yang masih cukup seru. Sebagian berpendapat bahwa peran bronkodilator cukup bermanfaat dan sebagian lagi tidak bermanfaat. Alasan yang kurang mendukung pemberian bronkodilator adalah karena pada usia bayi peran bronkodilator kurang jelas. Pada keadaan bronkiolitis yang dominan adalan inflamasinya bukan bronkokonstriksinya sehingga yang harus diberikan adalah pemberian antiinflamasi bukan bronkodilator. ${ }^{14}$

Salah satu obat yang pernah digunakan adalah pemberian immunoglobulin terhadap RSV yang pernah dilaporkan oleh Rodriguez. ${ }^{17}$ Pada penelitian tersebut diberikan RSVIG kepada pasien dengan bronkiolitis yang dirawat di ICU. Hasilnya ternyata tidak berbeda bermakna dengan plasebo (albumin) dalam hal lama rawat baik di bangsal maupun di ICU.

Selain penggunaan obat-obatan, tatalaksana secara suportif sangat dibutuhkan seperti pemberian oksigen, hidrasi yang cukup, koreksi asam-basa dan elektrolit, serta nutrisi yang memadai. Tanpa memperhatikan terapi suportif, pemberian medikamentosa menjadi kurang bermanfaat. ${ }^{14-16}$

\section{Daftar Pustaka}

1. Pechere JC. Pneumonia no single definition. Dalam: Community aquired pneumonia in children. International Forum Series. Edisi pertama. Cambridge Medical Publications, Wellingborough 1995.h.1-6.

2. Prober CG. Pneumonia. Dalam: Behrman RE, Kliegman RM, Arvin AM, eds. Nelson textbook of pediatrics edisi ke-15. Saunders, Philadelphia 1996.h. 716-21.

3. Arguedas AG, Stutman HR, Marks MI. Bacterial pneumonias. Dalam: Chernick V, Kendig EL penyunting. Kendig's Disorders of the respiratory tract in children. Edisi kelima. Saunders, Philadelphia 1990.h. 371-94.

4. Al-Eidan FA, McElnay JC, Scott MG, Kearney MP, Corrigan J, Mc Connell JB. Use of a treatment protocol in the management of community acquiered lower respiratory tract infection. J Antimicrob Chemother 2000; 45:387-94

5. Sazawal S, Black RE, Jalla S, Mazumdar S, Sinha A, Bhan MK. Zinc supplementation reduces the incidenceof acute lower respiratory infections in infants and preschool children: a double blind, controlled trial. Pediatrics 1998; 102:1-5.

6. Sampertegui F, Estrel B, Camaniero V, Betancourt V, Izurieta R, Ortiz W, dkk. The beneficial effects of weekly low-dose vitamin A supplementation on acute lower respiratory infections and diarrhea in Ecuadorian children. Pediatrics 1999; 104:1-7.

7. Long SS. Pneumonia in older infants, children, and adolescents. Dalam: Schidlow DV, Smith DS, penyunting. Hanley \& Belfus, Philadelphia 1994.h.89-98.

8. Gotz M, Ponhold W. Pneumonia in children. Dalam: Torres A, Woodhead M, penyunting. Pneumonia, European Respiratory Monograph, 1997.h. 226-62.

9. Carroll KC. Laboratory diagnosis of lower respiratory tract infections: controversy and conundrums. J Clin Microbiol 2002; 40:3115-20.

10. Contopoulos-Ionnidis DG, Ionnidis JPA, Chew P, Lau J. Meta-analysis of randomized controlled trials on the comparative efficacy and safety of azithromycin against other antibiotics for lower respiratory tract infections. J Antimicrob Chemother 2001; 48:691-703.

11. Ferwerda A, Moll HA, Hop WCJ, Kouwenberg JM, Tjon Pian Gi CV, Robben SGF, dkk. Efficacy, safety and tolerability of 3 day azithromycin versus 10 day coamoxiclav in the treatment of children with acute lower respiratory tract infections. J Antimicrob Chemother 2001; 47:441-6. 
12. Farhat CK. Use of clarithromycin in respiratory infections in pediatrics. Modern Pediatr 1995; 31:1-8.

13. Orenstein DM. Bronchiolitis. Dalam Behrman RE, Kliegen RM, Arvin Am, penyunting. Nelson Texbook of Pediatrics. Edisi kelimabelas. Saunders, Philadelphia. h.1211-2.

14. Van Woensel JBM, van Aalderen WMC, Kimpen JLL. Viral lower respiratory tract infection in infants and young children. BMJ 2003; 327:36-40.

15. Garrison MM, Christakis DA, Harvey A, Cummings P, Davis RL. Stemic corticosteroids in infant bronchioli- tis: A meta-analysis. Pediatrics 2000; 105:44-55.

16. Van Woensel JBM, van Aalderen WMC, de Weerd W, Jansen NJG, van Gestel JPJ, Markhost DG, et al. Dexamethasone for treatment of patients mechanically ventilated for lower respiratory tract infection caused by respiratory syncytial virus. Thorax 2003; 58:383-7

17. Rodriguez WJ, Gruber WC, Groothuis JR, Simoes EAF, Rosas AJ, Lepow M, dkk. Respiratory syncytial virus immune globulin treatment of RSV lower respiratory ract infections in previously healthy children. Pediatrics 1997; 100:937-42. 